\title{
Japanese Tea Ceremony in the Industry of Health and Wellness Tourism
}

\author{
Joyce Say \\ Graduate School of Asia Pacific Studies, Ritsumeikan Asia Pacific, Japan
}

\begin{abstract}
Japanese tea function is known to be a conventional practice that includes the custom arrangement and show of matcha powdered (green tea), within the coffee bar. Tea function is one of the significant customary and contemporary societies that people have been doing throughout the most recent hundreds of years. In Japan, one of the notable Japanese societies is the Tea function. Very much like other wellbeing and health the travel industry exercises, going into the lunch nook gives individuals a loosening up climate, where it gives individuals a diminutive warmup rest to them and heart. It permits local people and global vacationers to encounter the most bona fide Japanese culture, that is available in Kyoto. Concerning in the wellbeing and health, they are considered as a quickly developing the travel industry. That permits sightseers to encounter a respectable quality life, during their visit. Particularly, it tends to be finished by investigating the real experience just as finding the inward quietness during tea function time. Where the fundamental reason in this paper center the part of how tea function give the unwinding environment. By abandoning the concerns, and keep the psyche and heart quiet, very much like a tea individual.
\end{abstract}

KEYWORDS: Health and Wellness Tourism Industry, Japanese Tea Ceremony, Kyoto, Traditional Culture.

\section{INTRODUCTION}

According to the World Health Organization, health is a state of complete physical, mental and social well- being and not merely the absence of disease or infirmity (Rédigé par La Rédaction, 2015). Recent studies demonstrate that wellness travelers are more discerning, more cultured and more affluent than many other tourists and their higher spending capacity is a vital contributor to wellness travel (Bambini, 2020). They are considered as a fast growing tourism industry, that allows tourists to experience a decent quality life, during their stay. Before the 16th century, the tea ceremony was about lavish and luxury, instead of using abundant and luxurious decorations people started looking towards plain looking things found in nature (Path of Cha, 2019). In Japan, one of the well-known Japanese cultures is the Tea ceremony. It is known to be a traditional practice that involves the ritual preparation and presentation of matcha (green tea powdered), inside of the tearoom. Just like other health and wellness tourism activities, entering the tea room gives people a relaxing atmosphere, where it gives people a short warmup rest in their mind and heart. This paper aims to introduce Japanese tea ceremonies and the concept of health and wellness tourism. Using Kimono Tea Ceremony Maikoya as a case study which provides both physical and mental health.

\section{JAPANESE TEA CEREMONY}

Japanese tea ceremony is known to be a traditional practice that involves the ritual preparation and presentation of matcha powdered (green tea), inside of the tearoom. Tea ceremony is one of the important traditional and contemporary cultures that individuals have been doing over the past centuries. Not only it allows local and international tourists to discover this authentic experience but also it encourages people to learn how to be patient when making tea. Japanese tea ceremony it's not just about making tea or serving it to guests. It's more about wanting to give positive impact to the society spiritually to motivate discipline and an improved way of thinking that must be continued by the younger generations (Ali et al, 2013). Since the ceremony itself leaves a deep impression on oneself who truly engages in the experience through the process is a sequence that express emotions and feelings and creates a distilled form and experience hence helping to increase understanding the reasons on the cultures preservation which is something to be instilled in every individual because it is a basis for good moral and personality (Ali et al, 2013). In order to recall, according to (Japan Home, 2019) listed out nine different steps that are required to conduct a tea ceremony as down below: 


\section{International Journal of Current Science Research and Review}

ISSN: 2581-8341

Volume 05 Issue 02 February 2022

DOI: 10.47191/ijesrr/V5-i2-05, Impact Factor: 5.825

IJCSRR@ 2022

Www.ijesrr.org

\begin{tabular}{|l|l|}
\hline Steps & Details \\
\hline First & $\begin{array}{l}\text { Send formal invitations to the guests } \\
\text { Keeping them simple and beautiful }\end{array}$ \\
\hline Second & $\begin{array}{l}\text { Start preparations } \\
\text { Cleans the room (Tatami) on the floor }\end{array}$ \\
\hline Third & $\begin{array}{l}\text { Guests need to spiritually prepare themselves } \\
\text { Wash their hands to cleanse themselves (symbolically of the dust of the outside world) }\end{array}$ \\
\hline Fourth & Everything is done in harmony (including cleaning) \\
\hline Fifth & Host needs to take silk (Fukusa) to represent his/her spirit \\
\hline Sixth & Start making tea, by putting three scoops of matcha and pour a small amount of hot water \\
\hline Seventh & Guests need to turn the bowl, to avoid drinking from the decorative sides \\
\hline Eighth & Eat sweets to avoid the bitterness of green tea \\
\hline Ninth & $\begin{array}{l}\text { Enjoy the tea } \\
\text { Clean the bowl } \\
\text { Bowl one more time as a sign of respect before leaving the room }\end{array}$ \\
\hline
\end{tabular}

Finally, tea ceremony is all about the social interaction between the hosts and the guests. How the hosts and the guests treat and respect each other through the basic bowing, drinking and eating. In additionally, the Japanese tea ceremony is more than just tea drinking and some say that is it similar as learning steps to a complicated elegant dance; that can be seen in a special event for the Japanese and has been an important tradition for their culture where they wear kimono, which is their traditional attire and attend the tea ceremony to drink green tea in Japanese tea bowl while relaxing and admiring the beauty of the ceremony also leaving all their life problems as they enter the tea room (Ali et al, 2013).

\section{KYOTO PREFECTURE: KIMONO TEA CEREMONY MAIKOYA}

Japan, Kyoto is one of the oldest prefectures, where the tea ceremony was born and remains its spiritual heart (Rowthorn, 2021). For over 1,000 years, but it was only around the 16th century that the practice took on the highly ritualized form by which it is known today (Rowthorn, 2021). At the same time, one of the famous well- known tea ceremonies, located in Kyoto prefecture. It's called Kimono Tea Ceremony Maikoya, whereas it offers traditional tea ceremonies in the historic Gion district and the Kyoto station area with the option of wearing kimono (Kimono Tea Ceremony Makikoya (n.d.). It allows the locals and international tourists to experience the most authentic Japanese culture, that is accessible in Kyoto every hour from nine a.m. to seven p.m. Kimono Tea Ceremony Maikoya is popular for dressing up in kimono, making your own tea, being served by Maiko, discovering cultural history, and drinking Japanese green tea in an authentic tea ceremony place and eating Japanese sweets. Especially, when knowing that in Japan, Kyoto prefecture, tea ceremony (the way of tea) is one of Japan's traditional cultural practices, and is a name given to an art that synthesizes the preparation and drinking of tea together with spirituality, history, architecture, the appreciation of handmade tea utensils (En Tea Ceremony Experience, 2014). As a matter of fact, in order to make a decent matcha (green tea), it takes decades for the host to master the art of serving tea (Japan Home, 2019). Considering that they are required to study philosophy, aesthetics, art and calligraphy, as well as learning meticulous preparations (Japan Home, 2019). Since the purpose of holding tea ceremony is to let guests feel enjoyment and peace too. Exclusively, back in the 16th century, the Japanese People created a new culture which consisted of such elements as the "Tea House", "Sukiya Style Architecture" and the "Wabi- Sabi" aesthetic of transience (Kaon \& Liotta, 2011). That instead of putting fancy decorations, there are more just natural designs with bamboo and tatami. Which gives an idea of preference for change in belief is deeply tied into the concept of wabi- sabi that is still valued in Japanese ceremony to this day (Path of Cha, 2019).

\section{THE CONCEPT OF HEALTH AND WELLNESS TOURISM}

The ideas of conducting health and wellness tourism is to improve the wellbeing of the tourists themselves. The term health can also be interpreted as an area that shares in the history of tourism, often with the same concepts of medical tourism, health- care tourism, and global healthcare services (Kim, Lee, and Ko, 2016). In recent studies demonstrate that wellness travelers are more discerning, 


\section{International Journal of Current Science Research and Review}

ISSN: 2581-8341

\section{Volume 05 Issue 02 February 2022}

DOI: 10.47191/ijcsrr/V5-i2-05, Impact Factor: 5.825

IJCSRR@ 2022

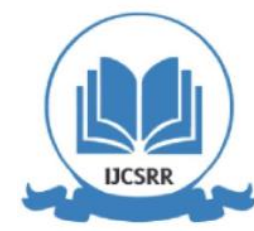

www.ijesrr.org

more cultured and more affluent than many other tourists and their higher spending capacity is a vital contributor to wellness travel (Bambini, 2020). They are considered as a fast growing tourism industry, that allows tourists to experience a decent quality life, during their stay. Especially, it can be done by exploring the authentic experience as well as discovering the inner silence during tea ceremony time. Moreover, ever since the 80's, health and wellness tourism have emerged and recognized as one of the most developed and growing sectors of today's thriving tourism industry and it has increased its activity worldwide (Quintela, Correia, and Costa,2016). Health and wellness tourism have always been clarify as the sum of all the relationship resulting from a journey by people whose motive, in whole or in part, is to maintain or promote their health and well-being, and who stay at least one night at a facility that is specifically designed to enable and enhance people's physical, psychological, spiritual and/ or social well- being (Voigt, Brown, and Howat, 2011).

\section{JAPANESE TEA CEREMONY IN HEALTH AND WELLNESS TOURISM}

In the health and wellness tourism industry, tea ceremony gives people a positive impact and teaches good characteristics that need to be instilled in everyone such as manners, beauty, simplicity, respect, appreciation, discipline, humbleness and kindness (Ali et al, 2013). It is not only about keeping as a traditional culture, but it's more about how it have reflect toward health and wellness tourism. Tea ceremony (Way of Tea), is to cultivate one's mind, body, and soul all together through everyday trainings of tea; which harmonize four basic concepts for the tea practitioners to follow: wa (harmony), kei (respect), sei (purity), and jyaku (tranquility) (Five Colleges, 2021). A way that it is not only culture but it is a part of the arts that harmony, purify, and relax. Usually, the interior of the tearoom have no fancy decorations, but just natural design with bamboo and tatami. This idea of preference for change in belief is deeply tied into the concept of wabi- sabi that is still valued in Japanese ceremony to this day (Path of Cha, 2019). Along with coordinate with the basic concepts of Wa, Kei, Sei and Jyaku, according to (Five Colleges, 2021) indicate, the followings:

\begin{tabular}{|l|l|}
\hline $\begin{array}{l}\text { Wa } \\
\text { (Harmony) }\end{array}$ & $\begin{array}{l}\text { To create a friendly relationship between the host and guest } \\
\text { Applicable to a basic rule in human society } \\
\text { Should be friendly to nature } \\
\text { Should only take what we need and never more }\end{array}$ \\
\hline $\begin{array}{l}\text { Kei } \\
(\text { Respect })\end{array}$ & $\begin{array}{l}\text { To show one's respect to others and nature and to be humble at all times } \\
\text { Doing so negates one's selfishness and thus enables one to attain peace of mind }\end{array}$ \\
\hline $\begin{array}{l}\text { Sei } \\
\text { (Purity) }\end{array}$ & $\begin{array}{l}\text { To obtain cleanliness both outside and inside } \\
\text { Wash one's hands and mouth before entering the tearoom } \\
\text { Attain physical purity } \\
\text { Empty one's mind through the act of making and drinking tea to attain spiritual purity }\end{array}$ \\
\hline $\begin{array}{l}\text { Jyaku } \\
\text { (Tranquility) }\end{array}$ & $\begin{array}{l}\text { To attain calmness in mind so that one is prepared to face anything at all times } \\
\text { Through achieving physical training and practicing making tea }\end{array}$ \\
\hline
\end{tabular}

\section{CONCLUSION}

Overall, Japanese tea ceremonies have become a popular trend for tourists who would love to visit Kyoto, Japan just to practice their traditional cultures. Despite the fact that there's even traveling magazines, television programs, or dramas that show what it is like to wear a kimono and serve as guests in the tea ceremony events. Even in bookstores, it talks about the historical background and some description of explaining what each etiquette manners means. From eating, drinking, serving tea, walking, bowing, tips on how to be respectful as a host and guests. But on the side of health and wellness tourism industry perspective views, , it allows individuals to find and know themselves during the silence. Which secretly, acting as a power that gives the courage of motivating inner self. To understand it more precisely, the Way of Tea is basically concerned with activities that are a part of everyday life, yet to master these requires great cultivation (Oka \& Muragishi, 2006). Moreover, another way of saying the Way of Tea is well defined as the Art of living, it is concern as for having proper environment that in the recreational wellness tourists, it have motiv- ations that interact strongly with attractions in the environment and to cultural aspects of a destination, in addition to having a highly positive attitude toward sustaining tourist attractions (Lim, Kim, and Lee, 2016). Since, health tours is defined as an area of special purpose tourism activities, where the motivation is to improve one's health and use facilities and services suiting the motivation (Kim, Lee, and Ko, 


\section{International Journal of Current Science Research and Review}

ISSN: 2581-8341

Volume 05 Issue 02 February 2022

DOI: 10.47191/ijesrr/V5-i2-05, Impact Factor: 5.825

IJCSRR@ 2022

2016). Where the main purpose in this paper focus the aspect of how tea ceremony provide the relaxation atmosphere. By leaving the worries behind, and keep the mind and heart calm, just like a tea person.

\section{REFERENCES}

1. Ali, A et al. (2013). Procedia- Social and Behavioral Sciences 106, 2390- 2396. 4th International Conference on New Horizons in Education. Significance of Japanese tea ceremony values with ceramic art interpretation.

2. Bambini, C. (2020, July 14). Heritage Hotels of Europe. Wellness Tourism: Which are the top trends and destinations? Retrieved from https://heritagehotelsofeurope.com/wellness-tourism-which-are-the-top-trends-and-destinations/

3. En Tea Ceremony Experience (2014). Japanese Tea Ceremony Experience in Kyoto En. Retrieved from http://www.teaceremonyen.com/

4. Five College Consortium (2021). Japanese Tea Ceremony. The Way of Tea. Retrieved from https://www.fivecolleges.edu/tea_ceremony

5. Japan Home. (2019, December 22). The art of the Japanese Tea Cermony. Retrieved from https://japanahome.com/journal/the-art-of-the-japanese-tea-ceremony/

6. Kaon, K. \& Liotta, S. J. (2011). Breaking and Mending: Proceedings of the 16th International Conference on ComputerAided Architectural Design Research in Asia, 71-80. Digital Tea House.

7. Kim, J. H. Lee, J. T., and Ko, G. T., (2016, May 26). Journal of Travel \& Tourism Marketing Satisfaction and Subjective Well Being of health tourists: The Case of Japanese and Korean Tourists.

8. Kimono Tea Ceremony Makikoya (n.d.). Official Websites. Traditional Tea Ceremony KYOTO. Retrieved from https://mai-ko.com/culture/tea-ceremony/.

9. Lim, J. Y., Kim. K. H., and Lee, J. T. (2016, March 1). Visitor Motivational Factors and Level of Satisfaction in Wellness Tourism: Comparison Between First- Time Visitors and Repeat Visitors.

10. Oka, M. and Muragishi, S. (2006, November 14 - 17). CAWSES International Workshop on Space Weather Modeling. The Earth Simulator Center, JAMSTEC, Yokohama, Japan. Japanese Tea Ceremony.

11. Path of Cha (2019, April 15). WABI- SABI and the Japanese Tea Ceremony. Retrieved from https://pathofcha.com/blogs/all-about-tea/wabi-sabi-and-the-japanese-tea-ceremony.

12. Quintela A. J., Correia, A. and Costa, C. (2016, January). Health, wellness and medical tourism - a conceptual approach. Enlightening Tourism. A Path making Journal, Vol 5. No 1 (2016) pp. 1- 18.

13. Rédigé par La Rédaction (2015, February 3). Health and Wellness Tourism: Where to got to be on top form? Retrieved from https://www.tourmag.com/Health-and-wellness-tourism-where-to-go-to-be-on-top-form_a72046.html

14. Rowthorn, C. (2021). Insider Kyoto. Kyoto Tea Ceremony. Retrieved from https://www.insidekyoto.com/kyoto-teaceremony

15. Voigt, C., Brown, G., and Howat, G. (2011). Wellness tourists: in search of transformation. Pg (1-10).

Cite this Article: Joyce Say (2022). Japanese Tea Ceremony in the Industry of Health and Wellness Tourism. International Journal of Current Science Research and Review, 5(2), 341-344 